\title{
Functional and Phenotypic Evidence for a Selective Loss of Memory T Cells in Asymptomatic Human Immunodeficiency Virus-infected Men
}

Carel J. M. van Noesel, Rob A. Gruters, Fokke G. Terpstra, Peter Th. A. Schellekens, Rene A. W. van Lier, and Frank Miedema Central Laboratory of the Netherlands Red Cross Blood Transfusion Service, and the Laboratory for Clinical and Experimental Immunology of the University of Amsterdam, 1006 AK, Amsterdam, The Netherlands

\begin{abstract}
In addition to a well-documented depletion of $\mathrm{CD4}^{+} \mathrm{T}$ helper cells in later stages of human immunodeficiency virus (HIV) infection, evidence has been provided for a specific unresponsiveness to triggering either by specific antigen in the context of autologous major histocompatibility molecules (self $+\mathbf{X}$ ) or anti-CD3 monoclonal antibodies (MAb) in both CD4 and CD8 cells from asymptomatic $\mathrm{HIV}$-infected individuals. In the present study we analyzed this unresponsiveness using mitogenic antibodies to distinct $T$ cell membrane receptors. $T$ cells from HIV-infected men who had normal numbers of $\mathrm{CD4}^{+} \mathrm{T}$ cells responded poorly to activation signals via the $\mathrm{CD} 3$ membrane antigen in both accessory cell-dependent as well as accessory cell-independent culture systems. A similar low response was observed in an anti-CD2-driven system. In contrast, proliferation induced by anti-CD3, anti-CD2, or the phorbol ester Phorbol myristate acetate could be normally enhanced by antiCD28 MAb. We demonstrated that this unresponsiveness is not due to a failure to induce early events required for activation, such as increased intracellular concentration of free calcium and activation of protein kinase $C$, but is caused by an imbalance between naive and memory $\mathrm{T}$ cells. In HIV-infected asymptomatic men, $\mathrm{CD}^{+}{ }^{+}$memory $\mathrm{T}$ cells are selectively depleted which results in a poor responsiveness to self $+\mathbf{X}$. These findings provide new insights that may have implications for our understanding of the immunopathogenesis of AIDS. (J. Clin. Invest. 1990. 86:293-299.) Key words: immunopathogenesis • human immunodeficiency virus • memory • $T$ cells $\cdot$ CD29/CD45R antigens
\end{abstract}

\section{Introduction}

The selective loss of $\mathrm{CD}^{+} \mathrm{T}$ helper cells in relatively late stages of human immunodeficiency virus (HIV) infection is well documented $(1,2)$. At first this was believed to be the only mechanism by which HIV does induce immunodeficiency leading to AIDS-related complex and acquired immunodeficiency syndrome (AIDS). However, next to quantitative effects of HIV infection, qualitative functional defects have been reported in $\mathrm{CD}^{+} \mathrm{T}$ cells from AIDS patients $(3,4)$. More recently, we

Address reprint requests to Frank Miedema, Ph.D., Central Laboratory of The Netherlands, Red Cross Blood Transfusion Service, P.O. Box 9406, 1006AK Amsterdam, The Netherlands.

Received for publication 20 June 1989 and in revised form 11 December 1989.

J. Clin. Invest.

(c) The American Society for Clinical Investigation, Inc. 0021-9738/90/07/0293/07 \$2.00

Volume 86, July 1990, 293-299 provided evidence that HIV infection affects the immune system before $\mathrm{CD}^{+} \mathrm{T}$ cell depletion can be noted (5). $\mathrm{T}$ cells from early asymptomatic HIV-infected persons, who still had normal numbers of circulating $\mathrm{CD}^{+} \mathrm{T}$ helper cells, had decreased $\mathrm{T}$ helper activity for polyclonal $\mathrm{B}$ cell differentiation $(5,6)$. Other investigators provided evidence that proliferative responses to foreign antigens, soluble or in the context of autologous major histocompatibility molecules (self $+\mathrm{X}$ ), but not to alloantigens or the lectin phytohemagglutinin, were decreased in a significant proportion of asymptomatic HIV-positive men (4, 7-10). Shearer et al. $(4,7,8)$ demonstrated a selective loss of $\mathrm{T}$ cell reactivity, both with respect to proliferation and generation of CTL in response to self $+X$ in early HIV-infected men. The $T$ cell nonresponsiveness to self $+X$ could be restored by rIL- 2 or by co-stimulation by self $+X$ plus allogeneic cells (ALLO) (4).

In a previous study we reported that $\mathrm{T}$ cells from HIV-infected asymptomatic men were relatively unresponsive to stimulation by soluble anti-CD3 monoclonal antibodies (MAb). This T cell unresponsiveness was shown to be intrinsic because it could not be corrected by the addition of normal donor monocytes as accessory cells (5).

Since $T$ cell responses to soluble anti-CD3 MAb, similar to antigen-specific responses are critically dependent on intimate contact between monocytes and T lymphocytes $(11,12)$, other $\mathrm{T}$ cell membrane receptors next to CD3/TCR may contribute to the observed defective response in T cells from HIV-infected men. Next to CD3/TCR involvement of CD2, CD11a and CD28 membrane molecules in human $\mathrm{T}$ cell activation has been demonstrated $(11,13,14)$. T cell activation through both the CD3/TCR complex and CD2 is accompanied by a rise in intracellular-free $\mathrm{Ca}^{2+}$ concentration $\left(\left[\mathrm{Ca}^{2+}\right]_{\mathrm{i}}\right)$ and activation of protein kinase $\mathrm{C}$ (PK-C), ${ }^{1}$ whereas it has been suggested that triggering via $\mathrm{CD} 28$ occurs through an alternative route independent of PK-C (14-17).

In this study we analyzed the $\mathrm{T}$ cell unresponsiveness in asymptomatic HIV-infected men in well-defined T cell activation systems using MAb against CD3, CD2, and CD28. Moreover, early biochemical events after triggering with anti-CD3 and $\mathrm{CD} 2 \mathrm{MAb}$ were measured. Our data indicate that the selective unresponsiveness in $T$ cells from asymptomatic HIV-infected men cannot be explained by a defect in the early intracellular signaling pathways. However phenotypical analysis revealed a selective depletion of CD29+ memory $T$ cells. This imbalance between naive and memory $T$ cells may well explain the observed selective unresponsiveness to self $+X$ and anti-CD3 MAb and may have consequences for anti-HIV specific immunity in early HIV infection.

1. Abbreviations used in this paper: MNC, mononuclear cells; PK-C, protein kinase $\mathrm{C}$. 


\section{Methods}

Monoclonal antibodies. The MAb used, CLB-T3/3 (IgG2a), CLB-T3/ 4.1 (IgG1), and CLB-T3/FITC (fluorescein iso-thio cyanaat conjugated) specific for CD3, anti-CD2 MAb CLB-T11.1/2 and CLB-T11.1/1, CLB-T4/FITC specific for CD4, CLB-T8/FITC specific for CD8, CLB-CD28/1 (15E8) specific for CD28 $(13,14,18)$ and FITC-conjugated goat anti-mouse IgG, were all produced by the Central Laboratory of the Netherlands Red Cross Blood Transfusion Service (CLB) (Amsterdam, The Netherlands). The CD2 MAb 9-1 was kindly provided by Dr. B. Dupont (Memorial Sloan-Kettering Cancer Institute, New York).

The expression of membrane antigens CD3, CD29, and CD45RA (see Tables III and IV) was determined using FITC-conjugated OKT3 (Ortho Pharmaceutical, Raritan, NJ) and phycoerythrin conjugated 4B4 and 2H4 MAb (Coulter Immunology, Hialeah FL). Membrane fluorescence was quantified on a EPICS-C cytofluorometer (Coulter Electronics Inc., Hialeah, FL). In these experiments 10,000 gated $\mathrm{CD}^{+}$lymphocytes were analyzed.

Cells. Mononuclear cells (MNC) were isolated by Percoll density gradient centrifugation from heparinized blood of seropositive and seronegative asymptomatic homosexuals selected for having normal numbers of circulating monocytes, $\mathrm{B}$ cells, and $\mathrm{CD} 4^{+}$cells. These men take part in a prospective cohortstudy in Amsterdam and have been described in detail before $(5,6)$.

MNC were depleted for CD45RA ${ }^{+} \mathrm{T}$ cells using the MAb $2 \mathrm{H} 4$ (Coulter Immunology) and anti-mouse Ig coated magnetic beads (dynabeads M450; Dynal A.S., Oslo, Norway).

Briefly, cells $\left(5.10^{6} / \mathrm{ml}\right)$ were incubated with $2 \mathrm{H} 4(10 \mu \mathrm{g} / \mathrm{ml})$ at $4^{\circ} \mathrm{C}$. After $1 \mathrm{~h}$ cells were washed twice and resuspended in PBS supplemented with $2 \%$ FCS. To each milliliter of this cell suspension, containing $5.10^{6}$ cells, $50 \mu \mathrm{l}$ of anti-mouse Ig coated dynabeads suspension was added. Finally, $2 \mathrm{H}^{+} \mathrm{T}$ lymfocytes were removed making use of a magnetic particle concentrator (Dynal MPC 1; Dynal A.S.).

$T$ cell proliferation assays. $T$ cell proliferation assays have been described in detail before $(11,14)$. In brief, flat bottom wells (Nunc, Roskilde, Denmark) were coated overnight at $4^{\circ} \mathrm{C}$ with anti-CD3 MAb, CLB-T3/3 (1 or $5 \mu \mathrm{g} / \mathrm{ml})$ in PBS. The plates were washed three times with PBS before use. The anti-CD2 MAb CLB-T11.1/2 (14) and 9-1 and the anti-CD28 MAb (CLB-CD28/1) (18) were all used in a final concentration of $1 \mu \mathrm{g} / \mathrm{ml} .4 \times 10^{4} \mathrm{MNC}$ were cultured at $37^{\circ} \mathrm{C}$ in Iscove's modified Dulbecco's medium supplemented with $5 \%$ human pooled serum and antibiotics on coated CLB-T3/3 plates for $5 \mathrm{~d}$ or in the presence of the anti-CD2 combination and $10^{4} 2,000$-rad irradiated healthy donor monocytes for $3 \mathrm{~d}$. The phorbol ester phorbol myristate acetate (PMA) was used at 10 and $100 \mathrm{ng} / \mathrm{ml}$ in the presence of irradiated monocytes in 3-d cultures. During the last $4 \mathrm{~h}$ of culture, 0.73 $\mathbf{k B q}\left[{ }^{3} \mathrm{H}\right]$ thymidine was added to measure cell proliferation.

Measurement of the free intracellular $\mathrm{Ca}^{2+}$ concentration and intracellular $\mathrm{pH}$. Cytoplasmic-free $\mathrm{Ca}^{2+}$ concentration was measured on a Shimadzu spectrofluorometer as described (19). MNC $\left(1.10^{6} / \mathrm{ml}\right)$ were loaded with Indo-1 in Hepes medium (pH 7.4) containing 132 $\mathrm{mM} \mathrm{NaCl}, 6 \mathrm{mM} \mathrm{KCl}, 1 \mathrm{mM} \mathrm{Na}_{2} \mathrm{HPO}_{4}, 5 \mathrm{mM}$ glucose, $20 \mathrm{mM}$ Hepes, $1 \mathrm{mM} \mathrm{CaCl}_{2}, 1 \mathrm{mM} \mathrm{MgSO}_{4}$, and $1 \%$ serum albumin (Calbiochem-Behring Corp., San Diego, CA) (1 $\mu$ M) (20). Anti-CD3 MAb CLB-T3/3 (10 $\mu \mathrm{g} / \mathrm{ml})$, anti-CD2 MAb CLB-T11.1/1, and T11.2/1 (10 $\mu \mathrm{g} / \mathrm{ml})$ or ionomycine $(1 \mu \mathrm{M})$ were added under stirring to the cell suspension.

Intracellular alkalinization induced by PMA in MNC was measured under similar conditions after loading of the cells with the $\mathrm{pH}$ sensitive dye BCECF ( $5 \mu \mathrm{M})$ according to the method described by Moolenaar et al. (19).

Statistical analysis. Statistical significance of the observed differences between studied groups was evaluated using the nonparametric two-sided Wilcoxon-Mann-Whitney rank test.

\section{Results}

Proliferative responses in $T$ cells from $H I V$-infected men. We previously described an accessory cell-independent $\mathrm{T}$ cell activation assay using immobilized anti-CD3 MAb $(11,21)$. In contrast to proliferative responses to antigen or soluble antiCD3 MAb that are critically dependent on accessory cells, this culture system allows one to study $\mathrm{T}$ cell activation by antiCD3 triggering independent of activation mediated by $\mathrm{CD} 2$, LFA-1, and other accessory molecules. In this system $T$ cells from asymptomatic $\mathrm{HIV}^{+}$men, with normal numbers of $\mathrm{CD}^{+} \mathrm{T}$ cells, showed a significantly $(P<0.01)$ lower proliferative response compared with those of $\mathrm{HIV}^{-}$men (Fig. $1 A$ ). In other $\mathrm{T}$ cell activation systems we $(5)$ and others $(22,23)$ already observed a decreased reactivity of both purified $\mathrm{CD}^{+}$as well as $\mathrm{CD}^{+} \mathrm{T}$ cells. This shows that the poor responsiveness to anti-CD3 MAb indeed is an intrinsic property of $T$ cells from HIV-infected individuals and cannot be accounted for by

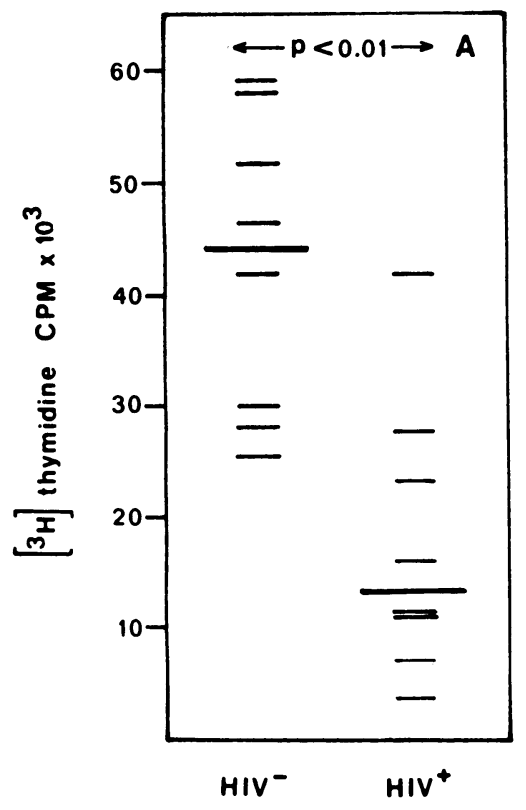

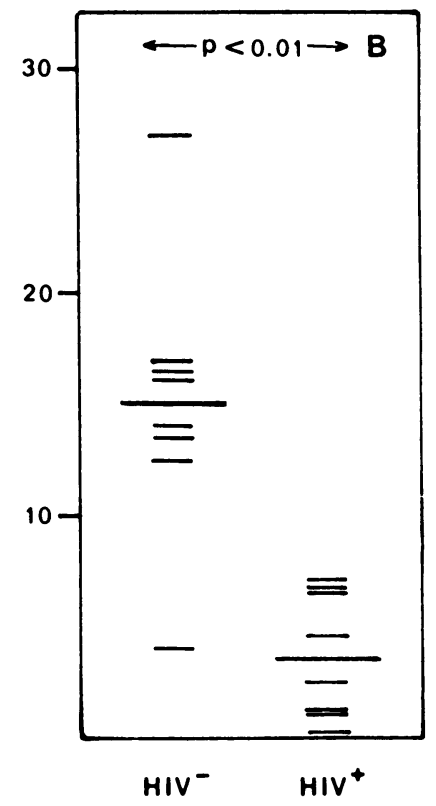

Figure 1. Anti-CD3 $(A)$ and anti-CD2 $(B)$ MAb induced proliferation of $\mathrm{T}$ cells from HIV-negative and HIV-positive homosexual men. 40,000 MNC were stimulated for $5 \mathrm{~d}$ with immobilized CLB-T $3 / 3,5 \mu \mathrm{g} / \mathrm{ml}(A)$ or for $3 \mathrm{~d}$ with a mitogenic anti-CD2 combination, MAb CLB-T11 and 9-1 at $1 \mu \mathrm{g} / \mathrm{ml}(B)$, in the presence of 10,000 normal monocytes that were 2,000-rad irradiated. Results are shown as the median of triplicate cultures. Thin bars represent results per individual, thick bars indicate the median. Background proliferation without MAb was $<200 \mathrm{cpm}$. Differences between patient groups were significant $(P<0.01)$ using for statistical comparison the nonparametric two-sided Wilcoxon-Mann-Whitney rank test. 
suppressive effects of $\mathrm{CD}^{+} \mathrm{T}$ cells. The unresponsiveness could be overcome by addition of exogeneous Il-2 (23a) as has been described in an antigen-specific system (4).

To test if the lack of activation is due to specific alterations at the membrane level, in particular the CD3/TCR complex, or reflects a more generalized unresponsiveness of the $T$ cell population, $T$ cell activation via other membrane receptors was tested. A comparable difference $(P<0.01)$ in T cell proliferation was observed when MNC of both groups were activated with a mitogenic combination of two anti-CD2 MAb $($ Fig. $1 B$ ). These activations were performed in the presence of an excess of normal monocytes to rule out a lack of accessory cell function in the system. Immunofluorescence studies revealed that the low anti-CD3- and anti-CD2-induced responses in HIV-infected men could not be attributed to altered expression of these antigens (data not shown). In contrast to the decreased response to anti-CD3 and anti-CD2 MAb, anti-

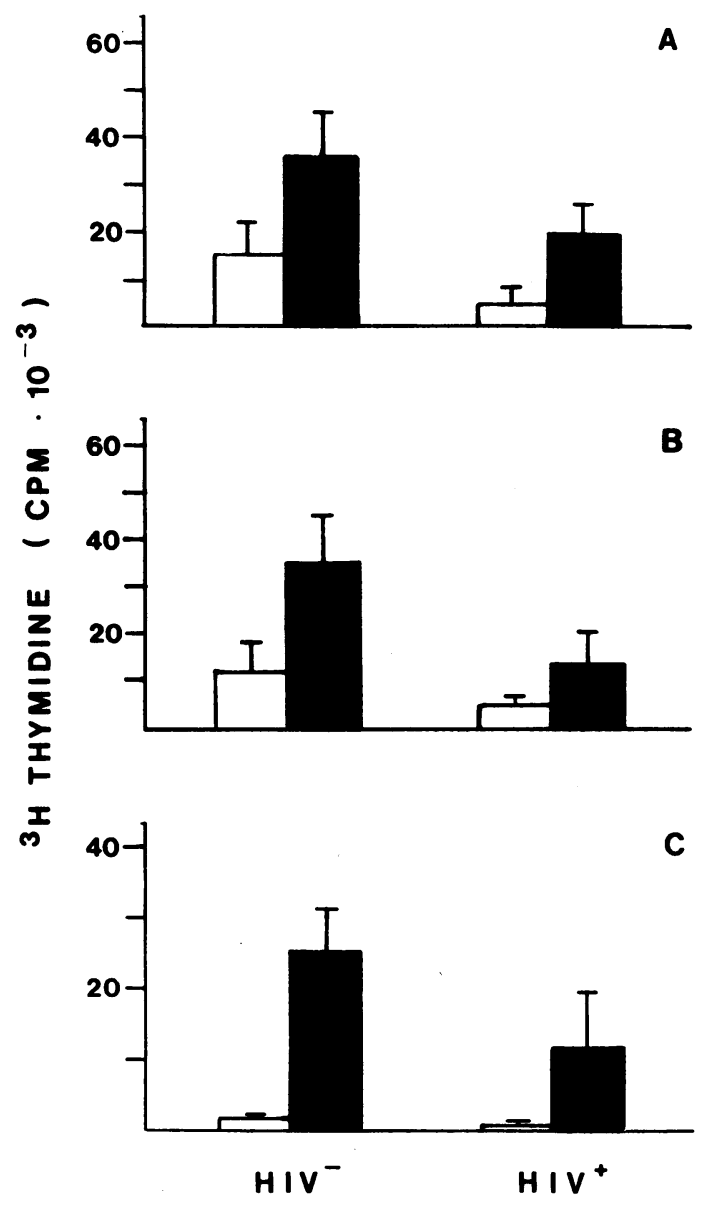

Figure 2. Effect of anti-CD28 MAb on T cell proliferation of HIV negative and positive men. $40,000 \mathrm{MNC}$ were cultured using $(A)$ the combination of MAb CLB-T11 and 9-1 $(1 \mu \mathrm{g} / \mathrm{ml}),(B)$ immobilized CLB-T3/3 $(1 \mu \mathrm{g} / \mathrm{ml})$, or (C) PMA (10 ng/ml) for 3,5 , and $3 \mathrm{~d}$, respectively (open bars). Anti-CD28 MAb (CLB-CD28/1) (18) was added to these cultures (closed bars) at $1 \mu \mathrm{g} / \mathrm{ml}$. All cultures were performed in the presence of $10,0002,000$-rad irradiated healthy donor monocytes. Results shown are the mean of data with $T$ cells from eight HIV negative and eight HIV positive homosexual men with standard deviation shown in brackets. Stimulation indices for anti-CD28 on $\mathrm{T}$ cells from $\mathrm{HIV}^{-}$men and $\mathrm{HIV}^{+}$men, respectively, were 2.4 and $4.8(A) ; 2.8$ and $2.4(B)$; and 22.1 and $26.1(C)$.
Table I. Intracellular $\mathrm{Ca}^{2+}$ Mobilization in $\mathrm{T}$ Cells from $\mathrm{HIV}^{-}$ and $\mathrm{HIV}^{+} \mathrm{Men}$

\begin{tabular}{|c|c|c|c|}
\hline \multirow[b]{2}{*}{ Study group } & \multicolumn{3}{|c|}{ Increase in $\left[\mathrm{Ca}^{2+}\right]_{i}$} \\
\hline & Anti-CD3 MAb & Anti-CD2 MAb & Ionomycine \\
\hline & \multicolumn{3}{|c|}{$n M$} \\
\hline \multicolumn{4}{|l|}{$\mathrm{HIV}^{-}$controls } \\
\hline 1 & 40 & 25 & nt \\
\hline 2 & 41 & 70 & 389 \\
\hline 3 & 69 & 74 & 476 \\
\hline 4 & 42 & 46 & 773 \\
\hline 5 & 102 & 94 & 874 \\
\hline Mean (SD) & $58(27)$ & $61(27)$ & $628(232)$ \\
\hline \multicolumn{4}{|l|}{$\mathrm{HIV}^{-}$men } \\
\hline 1 & 240 & 152 & 655 \\
\hline 2 & 55 & 111 & 309 \\
\hline 3 & 213 & 96 & 224 \\
\hline 4 & 68 & 98 & 696 \\
\hline 5 & 85 & 52 & 547 \\
\hline Mean (SD) & $132(67)$ & $101(36)$ & $486(210)$ \\
\hline \multicolumn{4}{|l|}{$\mathrm{HIV}^{+}$men } \\
\hline 1 & 119 & 114 & 677 \\
\hline 2 & 42 & 44 & 139 \\
\hline 3 & 44 & 38 & 358 \\
\hline 4 & 56 & 76 & 270 \\
\hline 5 & 115 & 78 & 382 \\
\hline Mean (SD) & 75 (39) & $70(31)$ & 365 (199) \\
\hline
\end{tabular}

CD28 MAb in synergy with anti-CD2 MAb (Fig. $2 A$ ), antiCD3 MAb (Fig. $2 B$ ), and PMA (Fig. $2 C$ ) induced strong proliferative responses in $\mathrm{T}$ cells from both $\mathrm{HIV}^{-}$and $\mathrm{HIV}^{+}$ men. The relative proliferation enhancement induced by the anti-CD28 MAb (CLB-CD28/1 [18]) was the same for the two groups as reflected by approximately equal stimulation indices for $\mathrm{HIV}^{+}$and $\mathrm{HIV}^{-}$men (Fig. 2), which suggests an intact CD28 activation pathway in HIV-infected men. The response however induced by the combination of anti-CD28 MAb and the respective primary stimuli in $\mathrm{T}$ cells from $\mathrm{HIV}$-infected men never equaled the response induced by these combinations in $\mathrm{T}$ cells from HIV negative men.

Analysis of intracellular activation pathways. Since the enhancement of $T$ cell activation by anti-CD28 was found to be relatively normal, it could be argued that the low proliferative responses via $\mathrm{CD} 2$ and $\mathrm{CD} 3$ might be caused by a failure to activate the intracellular signaling pathway shared by $\mathrm{CD} 3$ and CD2 receptors. Ligand binding to $\mathrm{CD} 2$ and $\mathrm{CD} 3$ results in hydrolysis of phosphatidyl-inositol-bisphosphate leading to the formation of at least two second messengers, inositol-triphosphate and diacylglycerol, responsible for a rise of $\left[\mathrm{Ca}^{2+}\right]_{i}$ and activation of PK-C, respectively (15-17). No significant differences in the anti-CD3 and anti-CD2 MAb-induced rises of $\left[\mathrm{Ca}^{2+}\right]_{i}$ could be demonstrated in $\mathrm{T}$ cells from five seronegative heterosexual and homosexual men and five healthy seropositive homosexual men (Table I). Since the early signaling after $\mathrm{CD} 3$ and $\mathrm{CD} 2$ receptor triggering was normal it was tested whether PMA, a direct activator of PK-C (24), was able to induce $T$ cell proliferation in $T$ cells from HIV-infected men. These proliferative responses were measured in the presence of excess of healthy donor monocytes since PMA-in- 
duced proliferation is dependent on accessory cells (25). Compared to $\mathrm{HIV}^{-}$homosexual men, $\mathrm{T}$ cells from seropositive men showed significantly lower proliferative responses to PMA (Table II). This could be due to a failure of PMA to activate PK-C in these cells. Alternatively it could be that $\mathrm{PK}-\mathrm{C}$ is normally activated but there is a lack of response distal from PK-C. PK-C phosphorylates, among other proteins, the $\mathrm{Na}^{+} / \mathrm{H}^{+}$antiporter (26) resulting in the activation of this translocator. PMA-induced rise of intracellular $\mathrm{pH}$ is a reflection of PK-C activation (27). In contrast to PMA-induced proliferation, qualitative (not shown) nor quantitative (Table II) differences in the PMA-induced alkalinization were observed with mononuclear cells of six randomly selected $\mathrm{HIV}^{-}$and $\mathrm{HIV}^{+}$men. This suggests that there is not a defect in early biochemical signalling events that underlies the unresponsiveness in $\mathrm{T}$ cells from HIV-infected men.

Selective loss of $C D 29^{+}$memory $T$ cells accounts for loss of $T$ cell reactivity in early HIV infection. With respect to their functional properties, unresponsiveness to self $+\mathrm{X}$, anti-CD2 and anti-CD3 MAb opposed to responsiveness to allogeneic cells, $\mathrm{T}$ cells from $\mathrm{HIV}^{+}$men show a striking resemblance to what recently has been postulated to be naive (immature) human $T$ cells (28-32). In normal donors memory $T$ cells are characterized by the expression of CD29 whereas naive cells lack CD29 and express high levels of CD45RA (28-32). To investigate whether the observed relative unresponsiveness in $T$ cells from HIV-infected men was caused by changes in the ratio of naive and memory $T$ cell populations, the expression

Table II. Diminished Proliferation but Normal PK-C Activation in $\mathrm{T}$ Cells from $\mathrm{HIV}^{+} \mathrm{Men}$ after Stimulation with PMA

\begin{tabular}{|c|c|c|c|}
\hline \multirow{3}{*}{ Study group } & \multicolumn{3}{|c|}{ PMA } \\
\hline & \multicolumn{2}{|c|}{ T cell proliferation } & \multirow{2}{*}{$\frac{\mathrm{pH}_{\mathrm{i}} \text { chang }}{100 \mathrm{ng} / \mathrm{m}}$} \\
\hline & $100 \mathrm{ng} / \mathrm{ml}$ & $10 \mathrm{ng} / \mathrm{ml}$ & \\
\hline \multicolumn{4}{|l|}{$\mathrm{HIV}^{-}$men } \\
\hline 1 & 17,952 & 13,966 & 0.05 \\
\hline 2 & 15,929 & 12,736 & nt \\
\hline 3 & 18,677 & 14,994 & 0.05 \\
\hline 4 & 20,617 & 15,238 & nt \\
\hline 5 & 10,344 & 4,561 & nt \\
\hline 6 & 17,752 & 14,897 & 0.09 \\
\hline 7 & 18,146 & 13,730 & nt \\
\hline 8 & 10,401 & 6,628 & nt \\
\hline Mean (SD) & $16,227(3,834)$ & $12,093(4,129)$ & \\
\hline \multicolumn{4}{|l|}{$\mathrm{HIV}^{+}$men } \\
\hline 1 & 10,091 & 720 & nt \\
\hline 2 & 12,311 & 723 & 0.07 \\
\hline 3 & 2,897 & 1,362 & nt \\
\hline 4 & 8,195 & 5,061 & nt \\
\hline 5 & 9,752 & 4,844 & nt \\
\hline 6 & 5,184 & 2,723 & 0.06 \\
\hline 7 & 2,714 & 1,421 & 0.08 \\
\hline Mean (SD) & $7,306(3,755)$ & $4,264(2,493)$ & \\
\hline
\end{tabular}

$50,000 \mathrm{MNC}$ were cultured for $3 \mathrm{~d}$ in the presence of irradiated healthy donor monocytes that were obtained by counterflow centrifugation elutriation and the indicated amount of PMA. PMA-induced proliferation of $\mathrm{T}$ cells from $\mathrm{HIV}^{+}$men was significantly decreased $(P<0.05)$.
Table III. Selective Loss of $\mathrm{CD}^{29^{+}}$Memory Cells in Asymptomatic HIV-infected Men

\begin{tabular}{|c|c|c|c|c|c|c|}
\hline \multirow[t]{2}{*}{ Group } & \multicolumn{2}{|c|}{$\mathrm{CD}^{+}$} & \multicolumn{2}{|c|}{$\mathrm{CD}^{+} \mathrm{CD}^{2} 9^{+}$} & \multicolumn{2}{|c|}{$\mathrm{CD}^{+}{ }^{+} \mathrm{CD} 45 \mathrm{RA}^{+}$} \\
\hline & $\%$ & $10^{9} /$ liter & $\%$ & $10^{9} /$ liter & $\%$ & $10^{9} /$ lite \\
\hline \multicolumn{7}{|c|}{$\mathrm{HIV}^{+}$men $^{*}$} \\
\hline 1 & 71 & 1.3 & 30 & 0.39 & 34 & 0.44 \\
\hline 2 & 76 & 1.3 & 35 & 0.46 & 30 & 0.39 \\
\hline 3 & 87 & 2.2 & 39 & 0.86 & 35 & 0.42 \\
\hline 4 & 82 & 2.2 & 18 & 0.40 & 64 & 1.14 \\
\hline 5 & 84 & 1.1 & 39 & 0.43 & 46 & 0.51 \\
\hline 6 & 75 & 1.1 & 32 & 0.35 & 55 & 0.61 \\
\hline 7 & 70 & 1.6 & 29 & 0.46 & 50 & 0.80 \\
\hline Mean & 78 & 1.5 & 32 & 0.48 & 45 & 0.65 \\
\hline SD & 6.6 & 0.48 & 7.3 & 0.17 & 12.5 & 0.36 \\
\hline \multicolumn{7}{|l|}{ Controls } \\
\hline Mean & 81 & 1.44 & 62 & 0.89 & 40 & 0.58 \\
\hline \multirow[t]{2}{*}{ SD } & 4.6 & 1.43 & 12.2 & 0.17 & 7.4 & 0.11 \\
\hline & \multicolumn{2}{|c|}{$\mathbf{n s} \mathbf{s}^{\ddagger}$} & \multicolumn{2}{|c|}{$P<0.02$} & \multicolumn{2}{|c|}{ ns } \\
\hline
\end{tabular}

* HIV-infected men used in this study were asymptomatic and had normal numbers of circulating $\mathrm{CD4}^{+} \mathrm{T}$ cells at the time of study. Clinical and laboratory findings in this group have been described in detail before (5).

${ }^{\ddagger} n s$, not significant.

of CD29 and CD45RA was tested. Table III shows that peripheral blood $\mathrm{T}$ cells from $\mathrm{HIV}^{+}$men contained a significantly decreased number of $\mathrm{CD}^{+} \mathrm{CD} 29^{+}$memory cells compared to $\mathrm{HIV}^{-}$controls. Except for one person the number CD45RA ${ }^{+}$ cells was unchanged in $\mathrm{HIV}^{+}$men. This is in agreement with results reported before on CD29 expression in early HIV infection (33).

Next it was investigated whether loss of memory $T$ cells could account for the decreased $T$ cell reactivity in HIV-infected men. In this experiment anti-CD3 MAb induced $\mathrm{T}$ cell proliferation, of MNC from a low and a high seropositive responder that were depleted for CD45RA ${ }^{+} \mathrm{T}$ cells, was measured. It can be noted that within an individual there is a positive correlation between the degree of responsiveness and the number of $\mathrm{CD} 29^{+} \mathrm{T}$ cells (Table IV). Depletion of

Table IV. Proliferation T Cells of Both $\mathrm{HIV}^{-}$and $\mathrm{HIV}^{+} \mathrm{Men}$ Is Enhanced by Depletion of CD45RA $A^{+}$Cells

\begin{tabular}{clcccc}
\hline & & \multicolumn{3}{c}{ Percent cells } \\
\cline { 3 - 4 } Donor & Cellfraction & $\mathrm{CD}^{+}$ & $\mathrm{CD}^{2} 9^{+}$ & CD45RA $^{+}$ & Proliferation $^{*}$ \\
\hline & & & & & $c p m 10^{3}$ \\
HIV $^{-}$ & & & & & \\
1 & MNC & 95 & 56 & 55 & 22,073 \\
& CD29 & 86 & 82 & 18 & 29,122 \\
HIV $^{+}$ & & & & & \\
1 & MNC & 95 & 29 & 70 & 3,649 \\
& CD29 & 90 & 56 & 28 & 10,539 \\
2 & MNC & 96 & 45 & 63 & 18,047 \\
& CD29 & 94 & 69 & 22 & 24,038
\end{tabular}

\footnotetext{
* T cell proliferation induced with coated anti-CD3 $\mathrm{MAb}(1 \mu \mathrm{g} / \mathrm{ml})$.

$\ddagger$ CD45RA depleted MNC fraction.
} 
$\mathrm{CD} 45 \mathrm{RA}^{+}$cells results, in both the control donor and the HIV infected individuals, in enhancement of anti-CD3 induced $\mathrm{T}$ cell proliferation. This effect is most clearly visible in the $\mathrm{HIV}^{+}$ donor with a low number of $\mathrm{CD} 29^{+} \mathrm{T}$ cells. These data suggest that circulating memory $T$ cells in HIV-infected men are competent and that the impaired $\mathrm{T}$ cell reactivity is based on an imbalance of $T$ cell subsets.

\section{Discussion}

In this study we have shown that $\mathrm{T}$ cells from asymptomatic HIV-infected men are relatively unresponsive to activation via CD2 and the CD3/TCR complex. These cells, however, have a quite normal response to activation signals provided by antiCD28 MAb. The unresponsiveness is not caused by a failure to initiate an early biochemical messenger in the intracellular signal transduction route, since both the rise in $\left[\mathrm{Ca}^{2+}\right]_{i}$ induced by anti-CD3 and anti-CD2 MAb and PK-C activation by PMA appear to be normal. Functional and phenotypical studies presented in this paper suggest that this unresponsiveness is caused by an imbalance between naive and memory $\mathrm{T}$ cells in early HIV-infected men. Table V summarizes the data with regard to functional properties of $T$ cells from early HIV-infected men and naive and memory $T$ cells as they have been described in normal donors. $\mathrm{T}$ cells from asymptomatic $\mathrm{HIV}^{+}$ men and naive $\mathrm{CD}^{2} 9^{-} \mathrm{CD}^{-} \mathrm{RRA}^{+}$normal donor $\mathrm{T}$ cells respond to PHA, alloantigens, and Il-2, but have a poor proliferative response to soluble and virus-specific antigens, anti-CD3 MAb and mitogenic combinations of anti-CD2 $\operatorname{MAb}(3,5,6$, $15,28-32,34)$. In our laboratory it was demonstrated that the poor response to anti-CD3 and anti-CD2 MAb in naive T cells could be enhanced by co-stimulation with anti-CD28 MAb although the responses in naive $T$ cells remained lower than those in memory $\mathrm{T}$ cells (de Jong et al., manuscript in preparation). Moreover, memory $\mathrm{T}$ cells but not naive normal $\mathrm{T}$ cells nor $\mathrm{T}$ cells from $\mathrm{HIV}^{+}$men produce gamma interferon (31, 35). At present the cell biological mechanisms underlying the functional differences between naive and memory cells are not known.

In addition to these functional data, we demonstrated that in asymptomatic HIV-infected men there is a specific loss of $\mathrm{CD} 29^{+} \mathrm{T}$ cells. In these men the number of $\mathrm{CD} 29^{+}$cells was decreased twofold compared to HIV-negative men, without a

Table V. T Cells from Asymptomatic HIV-infected Men Are Functionally Identical to Naive T Cells*

\begin{tabular}{|c|c|c|c|}
\hline $\begin{array}{l}\text { Functional activity } \\
\text { (response to) }\end{array}$ & $\begin{array}{l}\text { Memory } \\
\text { CD29 }^{+}\end{array}$ & $\begin{array}{l}\text { Naive } \\
\text { CD29- }\end{array}$ & $\begin{array}{l}\text { T cells in } \\
\text { early HIV } \\
\text { infection }\end{array}$ \\
\hline Antigen $(\mathbf{S}+\mathbf{X})$ & +++ & - & - \\
\hline Alloantigens & +++ & +++ & +++ \\
\hline PHA & +++ & +++ & +++ \\
\hline $\mathrm{A}-\mathrm{CD} 3$ & +++ & + & + \\
\hline $\mathrm{A}-\mathrm{CD} 3+\mathrm{A}-\mathrm{CD} 28$ & +++ & +++ & +++ \\
\hline $\mathrm{A}-\mathrm{CD} 2$ & ++ & + & + \\
\hline $\mathrm{A}-\mathrm{CD} 2+\mathrm{A}-\mathrm{CD} 28$ & ++ & ++ & ++ \\
\hline INF gamma production & +++ & + & - \\
\hline Helper activity & +++ & + & - \\
\hline
\end{tabular}

\footnotetext{
* For references see the text.
}

significant increase in the expression of CD45RA. Similar results were recently published by De Martini et al. (33). Lack of changes in CD45RA expression upon in vitro activation and low CD45RA expression on naive CD29- neonatal T cells has been reported (28), which may indicate that changes in CD29 expression may not necessarily be paralleled by changes in CD45RA expression. By depletion of $\mathrm{CD}^{4} 5 \mathrm{RA}^{+}$cells enhancement of $\mathrm{T}$ cell proliferation was achieved. This supports the option that the observed proliferative unresponsiveness can be accounted for by a disturbed ratio of naive and memory $\mathrm{T}$ cells. Minor qualitative defects in circulating CD29+ $\mathrm{T}$ cells, however, cannot be fully excluded.

With respect to the mechanism by which HIV infection results in an imbalance between naive and memory $T$ cells in asymptomatic HIV-infected men, one can envisage at least three possible explanations. Since retroviruses preferentially integrate in proliferating cells (36) this would implicate that memory $\mathrm{T}$ cells upon antigenic activation in vivo might be the main target cells to be infected, to produce HIV, and to die or to be efficiently cleared by HIV-specific cytotoxic T cells (37, 38). Elevated renewal of the $T$ cell pool by influx of naive $T$ cells may keep the absolute number of $T$ cells constant but results in an increase of the number of CD29- $C D 45 \mathrm{RA}^{+}$naive $T$ cells. On the other hand it can be postulated that HIV indirectly interferes with $T$ cell education and maturation by infection of antigen-presenting cells resulting in lowered expression of class II MHC molecules (39-42) and diminished accessory function $(5,41-43)$. This also would result in elevated numbers of naive $T$ cells that fail to respond to antigenic stimuli due to their intrinsic functional properties. Finally, it could be that by direct infection of T cells HIV induces an unresponsiveness to antigenic stimulation and a failure to differentiate from naive precursors to mature memory cells. In a recent paper Linette et al. (44) observed selective defects in early activation of cultured $\mathrm{T}$ lymphocytes obtained from normal donors that had been infected with HIV in vitro. In that modelsystem, where as many as $40 \%$ of the anti-CD3 and Il-2-activated cells in culture expressed HIV antigens, functional defects most likely result from direct effects of HIV infection of T cells. In HIV-infected individuals, however, only $0.01 \%$ of peripheral blood leukocytes are infected with HIV or express HIV antigens (45), ruling out the possibility that unresponsiveness observed in $\mathrm{T}$ cells is directly due to infection with HIV.

The finding of a generalized functional impairment in $T$ cells early in the course of HIV infection, suggests a more complex interaction between HIV and the immune system than was initially believed. An early effect of HIV infection on $T$ cell responses to self $+X$, including the anti-HIV response (46), may disturb the balance between virus and host defense. Data from our laboratory indicate that early after seroconversion in clinically healthy men who have stable $\mathrm{CD} 4^{+} \mathrm{T}$ cell numbers, only low virulent HIV variants can be isolated. During the course of infection more virulent HIV variants arise that are associated with $\mathrm{CD} 4^{+} \mathrm{T}$ cell loss and development of disease $(47,48)$. The combined immunological and virological findings in our laboratory suggest that the development of more virulent variants may be controlled by anti-HIV immunity $(37,38,49)$ and that decreased responses to self $+X$ allow for more overt HIV replication resulting in the emergence of virulent $\mathrm{HIV}$ variants and subsequent $\mathrm{CD} 4^{+}$cell depletion and development of disease $(48,50)$. 


\section{Acknowledgments}

We thank Drs. Jan Karel Eeftinck Schattenkerk, Sven Danner, Joep M. A. Lange, and Frank de Wolf for providing patient material and clinical data; and our colleagues, Dr. M. Tersmette for discussions, and Drs. C. J. Lucas and A. Verhoeven for careful review of the manuscript.

\section{References}

1. Melbye, M., R. J. Biggar, P. Ebbesen, J. J. Goedert, V. Faber, I. Lorenzen, P. Skinhoj, R. C. Gallo, and W. A. Blattner. 1986. Longterm seropositivity for human T-lymphotropic virus type III in homosexual men without the acquired immunodeficiency syndrome: development of immunologic and clinical abnormalities. Ann. Intern. Med. 104:496-500.

2. Fahey, J. L., H. E. Prince, M. Weaver, J. Groopman, B. Visscher, K. Schwartz, and R. Detels. 1984. Quantitative Changes in T helper or suppressor/cytotoxic lymphocyte subsets that distinguish acquired immune deficiency syndrome from other immune subsets disorders. JAMA (J. Am. Med. Assoc.) 76:95-100.

3. Lane, H. C., J. L. Depper, W. C. Greene, G. Whalen, T. A Waldmann, and A. S. Fauci. 1985. Qualitative analysis of immune function in patients with the acquired immunodeficiency syndrome. N. Engl. J. Med. 313:79-84.

4. Shearer, G. M., D. C. Bernstein, K. S. K. Tung, C. S. Via, R. Redfield, S. Z. Salahuddin, and R. C. Gallo. 1986. A model for the selective loss of major histocompatibility complex self-restricted $\mathrm{T}$ cell immune responses during the development of acquired immune deficiency syndrome (AIDS). J. Immunol. 137:2514-2521.

5. Miedema, F., A. J. C. Petit, F. G. Terpstra, J. K. M. E. Schattenkerk, F. De Wolf, B. J. M. Al, M. Roos, J. M. A. Lange, S. A. Danner, J. Goudsmit, and P. T. A. Schellekens. 1988. Immunological abnormalities in human immunodeficiency virus (HIV)-infected asymptomatic homosexual men. HIV affects the immune system before $\mathrm{CD}^{+}{ }^{+} \mathrm{T}$ helper cell depletion occurs. J. Clin. Invest. 82:1908-1914.

6. Terpstra, F. G., B. J. M. Al, M. Th. L. Roos, F. De Wolf, J. Goudsmit, P. T. Schellekens, and F. Miedema. 1989. Longitudinal study of leukocyte functions in homosexual men seroconverted for HIV: rapid and persistent loss of B-cell function after HIV infection. Eur. J. Immunol. 19:667-673.

7. Shearer, G. M., S. M. Payne, L. J. Joseph, and W. E. Biddison. 1984. Functional $T$ lymphocyte immune deficiency in a population of homosexual men who do not exhibit symptoms of acquired immune deficiency syndrome. J. Clin. Invest. 74:496-506.

8. Shearer, G. M., S. Z. Salahuddn, P. D. Markham, L. J. Joseph S. M. Payne, P. Kriebel, D. C. Bernstein, W. E. Biddison, M. G. Sarngadharan, and R. C. Gallo. 1985. Prospective study of cytotoxic $T$ lymphocyte responses to influenza and antibodies to human $\mathrm{T}$ lymphotropic virus-III in homosexual men. J. Clin. Invest. 76:1699-1704.

9. Giorgi, J. V., J. L. Fahey, D. C. Smith, L. E. Hultin, H. L. Cheng, R. T. Mitsuyasu, and R. Detels. 1987. Early effects of HIV on CD4 lymphocytes in vivo. J. Immunol. 138:3725-3730.

10. Roos, M. Th. L., F. Miedema, J. K. M. Eeftink Schattenkerk, F. De Wolf, J. Goudsmit, J. M. A. Lange, S. A. Danner, T. A. Out, and P. T. A. Schellekens. 1989. Cellular and humoral immunity in various cohorts of male homosexuals in relation to infection with Human Immunodeficiency Virus. Neth. J. Med. 34:132-141.

11. Van Noesel, C. J. M., F. Miedema, M. Brouwer, M. A. De Rie, L. A. Aarden, and R. A. W. Van Lier. 1988. Regulatory properties of LFA-1 alpha and beta chains in human T-lymphocyte activation. $\mathrm{Na}$ ture (Lond.). 333:850-852.

12. Palacios, R. 1985. Mechanisms by which accessory cells contribute in growth of resting $\mathrm{T}$ lymphocyte initiated by OKT 3 antibody. Eur. J. Immunol. 15:645-651.

13. Van Lier, R. A. W., J. H. A. Boot, E. R. De Groot, and L. A. Aarden. 1987. Induction of T-cell proliferation with anti-CD3 switch variant monoclonal antibodies: effects of heavy chain isotype in monocyte-dependent systems. Eur. J. Immunol. 17:1599-1604.

14. Van Lier, R. A. W., M. Brouwer, and L. A. Aarden. 1988. Signals involved in T-cell activation. T-cell proliferation induced through the synergistic action of anti-CD28 and anti-CD2 monoclonal antibodies. Eur. J. Immunol. 18:167-172.

15. Imboden, J. B., and J. D. Stobo. 1985. Transmembrane signalling by T-cell antigen receptor. J. Exp. Med. 161:446-456.

16. Alcover, A., M. J. Weiss, J. F. Daley, and E. L. Reinherz. 1986 The T11 glycoprotein is functionally linked to a calcium channel in precursor and mature T-lineage cells. Proc. Natl. Acad. Sci. USA. 83:2614-2618.

17. Weiss, A., B. Manger, and J. B. Imboden. 1986. Synergy between the T3/antigen receptor complex and Tp44 in activation of human T cells. J. Immunol. 137:819-825.

18. Van Lier, R. A. W., M. Brouwer, R. deJong, M. Groot, E. de Groot, and L. A. Aarden. 1989. Functional properties of the human T-cell differentiation antigen CD28. In Leukocyte Typing. Vol. IV. W. Knapp, editor. Oxford University Press, Oxford. 353-355.

19. Moolenaar, W. H., R. Y. Tsien, P. T. Van der Saag, and S. W. De Laat. 1983. $\mathrm{Na}^{+} / \mathrm{H}^{+}$exchange and cytoplasmic $\mathrm{pH}$ in the action of growth factors in human fibroblasts. Nature (Lond.). 304:645-648.

20. Grynkiewicz, G., M. Poenie, and R. Y. Tsien. 1985. A new generation of $\mathrm{Ca} 2+$ indicators with greatly improved fluorescence properties. J. Biol. Chem. 260:3440-3450.

21. Van Lier, R. A. W., M. Brouwer, V. I. Rebel, C. J. M. Van Noesel, and L. A. Aarden. 1989. Immobilized anti-CD3 monoclonal antibodies induce accessory-cell-independent lymphokine production, proliferation and helper activity in human T lymphocytes. Immunol ogy. In press.

22. Hofmann, B., K. D. Jakobsen, N. Odum, E. Dickmeiss, P. Platz, L. P. Ryder, C. Pedersen, L. Mathiesen, I. Bygbjerg, V. Faber, and A. Svejgaard. 1989. HIV-induced immunodeficiency. Relatively preserved phytohemagglutinin as opposed to decreased pokeweed mitogen responses may be due to possibly preserved responses via CD2/ phytohemagglutinin pathway. J. Immunol. 142:1874-1880.

23. Bentin, J., C. Tsoukas, J. A. McCutchan, S. E. Spector, D. D. Richman, and J. H. Vaughan. 1989. Impairment in T-lymphocyte responses during early infection with the human immunodeficiency virus. J. Clin. Immunol. 9:159-168.

23a.Gruters, R. A., F. G. Terpstra, R. de Jong, C. J. M. van Noesel, R. A. W. van Lier, and F. Miedema. 1990. Selective loss of T cell functions in different stages of HIV infection. Eur. J. Immunol. In press.

24. Nishizuka, Y. 1984. The role of protein kinase $C$ in cell surface signal transduction and tumor promotion. Nature (Lond.). 308:693698.

25. Manger, B., A. Weiss, J. B. Imboden, T. Laing, and J. D. Stobo. 1987. The role of protein kinase $C$ in transmembrane signalling by the $T$ cell antigen receptor complex. J. Immunol. 139:2755-2760.

26. Boron, W. F. 1984. Cell activation. The basic connection. $\mathrm{Na}$ ture (Lond.). 312:312-312.

27. Moolenaar, W. H., L. G. J. Tertoolen, and S. W. De Laat. 1984 Phorbol ester and diacylglycerol mimic growth factors in raising cytoplasmic pH. Nature (Lond.). 312:371-374.

28. Sanders, M. E., M. W. Makgoba, S. O. Sharrow, D. Stephany, T. A. Springer, H. A. Young, and S. Shaw. 1988. Human memory T lymphocytes express increased levels of three cell adhesion molecules (LFA-3, CD2, and LFA-1) and three other molecules (UCHL-1, CDw29 and Pgp-1) and have enhanced IFN-gamma production. $J$. Immunol. 140:1401-1407.

29. Tedder, T. F., L. T. Clement, and M. D. Cooper. 1985. Human lymphocyte differentiation antigens HB-10 and HB-11: I ontogeny of antigen expression. J. Immunol. 134:2983-2988.

30. Morimoto, C. N., N. L. Letvin, J. A. Distaso, W. R. Aldrich and S. F. Schlossman. 1985. The isolation and characterization of the human suppressor inducer T cell subset. J. Immunol. 134:1508-1515. 
31. Sanders, M. E., M. W. Makgoba, C. H. June, H. A. Young, and S. Shaw. 1989. Enhanced responsiveness of human T cells to CD2 and CD3 receptor mediated activation. Eur. J. Immunol. 19:803-808.

32. Merkenschlager, M., L. Terry, R. Edwards, and P. C. L. Beverley. 1988. Limiting dilution analysis of proliferative responses in human lymphocyte populations defined by the monoclonal antibody UCHL1: implications for differential CD45 expression in T cell memory formation. Eur. J. Immunol. 18:1653-1661.

33. De Martini, R. M., R. R. Turner, S. C. Formenti, D. C. Boone, P. C. Bishop, A. M. Levine, and J. W. Parker. 1988. Peripheral blood mononuclear cell abnormalities and their relationship to clinical course in homosexual men with HIV infection. Clin. Immunol. Immunopathol. 46:258-271.

34. Hofmann, B., B. Orskov Lindhardt, J. Gerstoft, C. Sand Petersen, P. Platz, L. P. Ryder, N. Odum, E. Dickmeiss, P. B. Nielsen, S. Ullman, and A. Svejgaard. 1987. Lymphocyte transformation response to pokeweed mitogen as a marker for the development of AIDS and AIDS related symptoms in homosexual men with HIV antibodies. Br. Med. J. 295:293-296.

35. Murray, H. W., D. A. Scavuzzo, C. D. Kelly, B. Y. Rubin, and R. B. Roberts. 1988. T4+ cell production of interferon gamma and the clinical spectrum of patients at risk for and with acquired immunodeficiency syndrome. Arch. Intern. Med. 148:1613-1616.

36. Gowda, S. D., B. S. Stein, N. Mohagheghpour, C. J. Benike, and E. G. Engleman. 1989. Evidence that T cell activation is required for HIV-1 entry in CD4 ${ }^{+}$lymphocytes. J. Immunol. 142:773-780.

37. Siliciano, R. F., T. Lawton, C. Knall, R. W. Karr, P. Berman, T. Gregory, and E. L. Reinherz. 1988. Analysis of host-virus interactions in AIDS with anti-gp120 T cell clones: effect of HIV sequence variation and a mechanism for $\mathrm{CD}^{+}$cell depletion. Cell. 54:561-575.

38. Lanzavecchia, A., E. Roosnek, T. Gregory, P. Berman, and S. Abrignani. 1988. T cells can present antigen such as HIV gp120 targeted to their own surface molecules. Nature (Lond.). 334:530-532.

39. Belsito, D. V., M. R. Sanchez, R. L. Baer, F. Valentine, and G. J. Thorbecke. 1984. Reduced Langerhans' cell Ia antigen and ATPase activity in patients with the acquired immunodeficiency syndrome. N. Engl. J. Med. 310:1279-1282.

40. Petit, A. J. C., F. G. Terpstra, and F. Miedema. 1987. HIV infection down-regulates HLA-class II expression and induces differentiation in promonocytic U937 cells. J. Clin. Invest. 79:1883-1889.

41. Eales, L. J., J. Farrant, M. Helbert, and A. J. Pinching. 1988. Peripheral blood dendritic cells in persons with AIDS and AIDS re- lated complex: loss of high intensity class II antigen expression and function. Clin. Exp. Immunol. 71:423-427.

42. Kruisbeek, A. M., J. J. Mond, B. J. Fowlkes, J. A. Carmen, S. Bridges, and D. L. Longo. 1985. Absence of the Lyt-2-, L3T4+ lineage of $\mathrm{T}$ cells in mice treated neonatally with anti I-A correlates with absence of intrathymic I-A-bearing antigen-presenting cell function. $J$. Exp. Med. 161:1029-1047.

43. Petit, A. J. C., M. Tersmette, F. G. Terpstra, R. E. Y. De Goede, R. A. W. Van Lier, and F. Miedema. 1988. Decreased accessory cell function by human monocytic cells after infection with HIV. J. Immunol. 140:1485-1489.

44. Linette, G. P., R. J. Hartzman, J. A. Ledbetter, and C. H. June 1988. HIV-I-infected T cells show a selective signalling defect after perturbation of CD3/antigen receptor. Science (Wash. DC). 241:573576.

45. Schnittman, S. M., M. C. Psallidopoulos, H. C. Lane, L. Thompson, M. Baseler, F. Massari, C. H. Fox, N. P. Salzman, and A. S. Fauci. 1989. The reservoir for HIV-1 in human peripheral blood is a $\mathrm{T}$ cell that maintains expression of CD4. Science (Wash. DC). 245:305-308.

46. Berzofsky, J. A., A. Bensussan, K. B. Cease, J. F. Bourge, R. Cheynier, Z. Lurhuma, J.-J. Salaün, R. C. Gallo, G. M. Shearer, and D. Zagury. 1988. Antigenic peptides recognized by $T$ lymphocytes from AIDS viral envelope-immune humans. Nature (Lond.). 334:706-708.

47. Tersmette, M., R. E. Y. De Goede, B. J. M. Al, I. N. Winkel, R. A. Gruters, H. T. M. Cuypers, H. G. Huisman, and F. Miedema. 1988. Differential syncytium-inducing capacity of human immunodeficiency virus isolates: frequent detection of syncytium-inducing isolates in patients with acquired immunodeficiency syndrome (AIDS) and AIDS-related complex. J. Virol. 62:2026.

48. Tersmette, M., R. A. Gruters, F. De Wolf, R. E. Y. De Goede, J. M. A. Lange, P. T. A. Schellekens, J. Goudsmit, J. G. Huisman, and F. Miedema. 1989. Evidence for a role of virulent HIV variants in the pathogenesis of AIDS obtained from studies on a panel of sequential HIV isolates. J. Virol. 63:2118-2125.

49. Plata, F., B. Autran, L. P. Martins, S. Wain-Hobson, M. Raphael, C. Mayaud, M. Denis, J. M. Guillon, and P. Debre. 1987. AIDS virus-specific cytotoxic $\mathrm{T}$ lymphocytes in lung disorders. Nature (Lond.). 328:348-351.

50. Cheng-Mayer, C., D. Seto, M. Tateno, and J. A. Levy. 1988. Biologic features of HIV-1 that correlate with virulence in the host. Science (Wash. DC). 240:80-82. 